\title{
Composition of Potential Heavy Metal Contaminants in Selected Liquid and Powdered Herbal Medicines Commonly Sold in Port Harcourt Metropolis, Nigeria
}

\author{
Ayobami Omozemoje Aigberua* \\ Department of Chemical Sciences, Faculty of Science, Niger Delta University, Wilberforce Island, Bayelsa \\ State, Nigeria
}

*Corresponding Author: Ayobami Omozemoje Aigberua' Department of Chemical Sciences, Faculty of Science, Niger Delta University, Wilberforce Island, Bayelsa State, Nigeria

\begin{abstract}
Four potential heavy metal contaminants (PHMC) were analyzed in nine (9) different brands of liquid and five (5) powdered herbal products commonly sold in Port Harcourt metropolis with a view to ascertaining their levels and comparing them with standard regulatory limits $(\mathrm{WHO})$ in order to establish if they are safe for human consumption. The samples were processed, digested and analyzed in triplicate using flame atomic absorption spectrophotometer (GBC Avanta PM6600 type). Concentration of heavy metals in liquid herbal products ranged from <0.001-2.541 ppm (copper) and 0.041-0.982 ppm (manganese), while chromium and cadmium were reportedly below detection limit in all test samples. Mean concentrations of copper and manganese in liquid herbal medicines were $0.38 \pm 0.79$ ppm and $0.47 \pm 0.27$ ppm respectively. On the other hand, the powdered herbs depicted heavy metal concentrations ranging from $0.049-0.143$ ppm (chromium), $0.437-2.587$ ppm (cadmium), while copper and manganese were reportedly below instrument detection limit. Mean concentrations of chromium and cadmium in finished powdered herbal products were $0.108 \pm 0.045 \mathrm{ppm}$ and $1.245 \pm 0.815 \mathrm{ppm}$ respectively. Apart from cadmium that exceeded WHO recommended limit in powdered herbal products, all other heavy metal contaminants were observed to be within recommended WHO limits and levels established by countries like Canada and Singapore. There was marked significant variation $(P<0.05)$ in the concentration of copper and manganese amongst the various liquid herbal medicines that were tested. Similarly, the finished powdered herbal products showed significant variation $(P<0.05)$ in concentrations of chromium and cadmium. Overall, the significant concentration of cadmium found in herbs of powdered form which are sold within the Port Harcourt metropolis is alarming and may be responsible for the high occurrence of kidney and liver health cases.
\end{abstract}

Keywords: potential heavy metal contaminants, world health organization, powdered herbal products, liquid herbal medicines.

\section{INTRODUCTION}

Typically, heavy metals possess higher specific gravity $\geq 5$ and molecular weight (Idris et al., 2013; Izah et al., 2016, 2017a; Izah and Aigberua, 2017; Izah et al., 2018a,b). They are also metallic elements with atomic weight greater than 40.0 (the atomic mass of Ca) (APHA, 1992; Umar et al., 2016). Heavy metals are natural constituents of the environment like air, water and soil. Heavy metals are both industrially and biologically important. They can also be produced by technical and industrial processes, thereby gaining importance as contaminants especially when their presence is been accelerated by human activities (Gasser et al., 2009; Odukoya and Abimbola, 2010). High anthropogenic constraint releases significant concentration of heavy metals into the environment, thereby threatening human existence (Onwordi et al., 2015). Some potential heavy metal contaminants such as chromium, copper, cadmium and manganese can become deleterious toxicants within vicinities of high anthropogenic burden. Some major activities that cause pollution to the environment include agricultural practices through the use of pesticides, food processing such cassava and oil palm processing wastes, oil and gas exploration and its associated activities such as dredging (Aigberua et al., 2016). The activities of makeshift refinery, wastes, oil and gas, runoff after rainfall have been reported to affect water quality. Studies have attributed the presence of pollutants gases and particulates in air to major human activities such as bush burning, gas flaring from oil bunkering 
activities and oil field exploration and production (Ogbeibu and Iyobosa, 2013; Ohimain, 2013; Ambe et al., 2015; Aigberua et al., 2016; Izah and Aigberua, 2017; Izah et al., 2017c). The soil is not exempted, as it is one of the major repositories of anthropogenic wastes. Waste water could also change water and soil quality (Aigberua et al., 2016; Izah and Aigberua, 2017; Izah et al., 2017b; Nduka and Aigberua, 2018). Environmental pollution affects the ecosystem and its biota (Aigberua et al., 2016; Izah et al., 2017b).

Studies have shown that most African countries including Nigeria continue to patronize the consumption of herbal medicines as an alternative to the ever increasing cost of orthodox health care systems (Pirzada et al., 2009; Onwordi et al., 2015), especially among rural dwellers who constitute about $70 \%$ of the population (Esimone et al., 2002; Onwordi et al., 2015). The side effects of certain synthetic drug therapies have encouraged many to embrace the green, organic nature of herbs which has been perceived as being relatively safe, accessible and economical (Carter, 2001; Chan, 2003).

Herbal medicines are mainly produced from plant root, leaf, stem and barks of tree. Plants are good indicators of the health of the soil and state of the air in which they are growing. Also, plants assimilate metal ions from their environment through atmospheric contamination from industries, packaging material, amongst others (Adepoju-Bello et al., 2012; Ekeanyanwu et al., 2013). They have been implicated as passive receptors of trace elements (fallout interception or root adsorption), but they also exert control over uptake or ejection of some element by appropriate physiological reactions. Thus, plants become intermediate reservoirs through which trace elements from soils, and partly from waters and air, move to man. USEPA reviews had identified $\mathrm{Cd}$ and $\mathrm{Hg}$ among the more toxic metals, while $\mathrm{Pb}, \mathrm{Cs}, \mathrm{As}, \mathrm{Cr}, \mathrm{Zn}, \mathrm{Ni}$, and $\mathrm{Cu}$ were frequently identified as metals causing biological/ecological harmful effects (Kabata-Pendias and Pendias, 2001). In small amounts, heavy metals are needed for sustenance of good health but in larger amounts they can become toxic or deleterious. Heavy metal toxicity can reduce energy levels and impair the functioning of the brain, lungs, kidney, liver, blood composition and other important organs. Long term hazards include physical, muscular, and neurological degenerative processes that mimic diseases such as multiple sclerosis, Parkinson's disease, Alzheimer's disease and muscular dystrophy. Recurrent long-term hazard of some metals and their compounds may even cause cancer (Jarup, 2003; Cooper et al., 2007; Bushra et al., 2011; Jaishankar et al., 2014; Umar et al., 2016).

Therefore, it is imperative to assess the levels of potential heavy metal contaminants (PHMC) in medicinal plants and herbal concoctions to ascertain the level of heavy metals. The present study aimed at quantitatively estimating the concentrations of four PHMC's namely $\mathrm{Cd}, \mathrm{Cr}, \mathrm{Cu}$ and $\mathrm{Mn}$ in nine (9) liquid and five (5) powdered herbal concoctions manufactured in Nigeria and marketed within the Port Harcourt metropolis. All the tested herbal products were branded but not all was registered with National agency for food and drug administration and control (NAFDAC); the local regulatory authority for the control of food and drugs administration in Nigeria. Only five of the nine liquid and three of the five powdered herbal concoctions were registered with NAFDAC. In spite of NAFDAC's endeavors at establishing regulation and control of herbal products in Nigeria, all stakeholders need to collaborate with the local regulatory authority to purge the country of fake and unhealthy drugs as crafty persons continue to come up with new channels of distributing contaminated and unhealthy herbal drug brands. The circumvention of NAFDAC certification processes by herbal medicine dealers poses a serious challenge to NAFDAC, especially with regards to regulation and control. Factors which may be responsible for non-registration of indigenous herbal drug dealers may include inadequate access to information on product registration, poor public perception of regulators (wherein acts of enforcement appear like a witch-hunt), non-clarification of laws and regulations to the regulated industry, inability to fulfill minimum criteria to be registered (that is, unavailability of clean and hygienic environment or equipment for herbal preparations) amongst others. This study is aimed at assessing the levels of potential heavy metal contaminants in selected liquid and powdered herbal medicines commonly sold in Port Harcourt Metropolis, with a view to comparing both herbal matrices in order to determine the public health risks associated with them, in terms of their residual heavy metal burdens. 
Composition of Potential Heavy Metal Contaminants in Selected Liquid and Powdered Herbal Medicines Commonly Sold in Port Harcourt Metropolis, Nigeria

\section{Materials ANd Methods}

\subsection{Sample Collection}

A total of fourteen (14) different brands of finished herbal products were purchased from retail outlets within Port Harcourt metropolis, Nigeria. Nine (9) of the herbal concoctions were of liquid matrix while five (5) samples were powdered. Not all fourteen brands were registered with NAFDAC as reflected in the labels. Five of the nine liquid and three of the five powdered herbs were duly registered with NAFDAC. On the other hand, some herbal drug samples were registered with both NAFDAC and NANTMP (National Association of Traditional Medicine Practitioner of Nigeria). All herbal products purchased were still within their stipulated expiration dates (Tables 1 and 2). The matrix effect (liquid or powdered) of different herbal products purchased was observed for elemental variations.

Purchase of the different herbal products was made on the basis of brand popularity, health benefits, and cost-effectiveness (affordability for people of different income classes).

Sample information (showing ingredients, expiration timeline, state of production in Nigeria and environ, and regulatory registration) is provided in tables 1 and 2 .

Table1. Source and ingredients of liquid herbal drugs sold within Port Harcourt metropolis

\begin{tabular}{|c|c|c|c|c|}
\hline $\begin{array}{l}\text { Herbal } \\
\text { drugs code }\end{array}$ & Ingredients & $\begin{array}{l}\text { Expiration } \\
\text { timeline }\end{array}$ & $\begin{array}{l}\text { State of } \\
\text { production in } \\
\text { Nigeria and } \\
\text { environ }\end{array}$ & $\begin{array}{l}\text { Regulatory } \\
\text { Registration }\end{array}$ \\
\hline UNC & $\begin{array}{l}\text { Aloe-vera plant, ginseng plant, moringa } \\
\text { plant. }\end{array}$ & $\begin{array}{l}\text { June } 2017- \\
\text { Dec } 2022\end{array}$ & Edo state & NANTMP \\
\hline YCB & $\begin{array}{l}\text { Aloe-vera, acinoa arventis, } \\
\text { aurantifolia, citrus } \\
\text { chenopodium } \\
\text { cinamomum aromatic. }\end{array}$ & $\begin{array}{l}\text { Dec } 2017- \\
\text { Dec } 2019\end{array}$ & Lagos state & NAFDAC \\
\hline RHB & $\begin{array}{l}\text { Curculigo pilosa-root }(40 \%), \text { uvaria } \\
\text { chamae-stem }(20 \%) \text {, citrullus colocynthis- } \\
\text { bark }(40 \%)\end{array}$ & $\begin{array}{l}\text { Aug } 2018- \\
\text { Aug } 2020\end{array}$ & Lagos state & NAFDAC \\
\hline UAM & Not specified & $\begin{array}{l}\text { Feb } 2017-\text { Jan } \\
2020\end{array}$ & Enugu state & NANTMP \\
\hline IGC & $\begin{array}{l}\text { Vernonia amygdalina (12\%), saccharum } \\
\text { officinarum }(11.5 \%) \text {, allium sativum }(13 \%) \text {, } \\
\text { cajanus cajan }(11.5 \%) \text {, zingiber officinale } \\
(0.5 \%) \text {, caramel }(1.5 \%) \text {, water (q.s). }\end{array}$ & $\begin{array}{l}\text { Feb } 2018- \\
\text { Feb } 2020\end{array}$ & Lagos state & NAFDAC \\
\hline SHM & $\begin{array}{l}\text { Herbs, roots, barks, leaves, aloe-vera, seeds } \\
\text { (Not clearly specified) }\end{array}$ & $\begin{array}{l}\text { Aug } 2018- \\
\text { Nov } 2021\end{array}$ & $\begin{array}{l}\text { Anambra } \\
\text { state }\end{array}$ & NANTMP \\
\hline EFM & $\begin{array}{l}\text { Selected natural herbs and roots (Not } \\
\text { specified). }\end{array}$ & $\begin{array}{l}\text { Jan } 2017-\text { Jan } \\
2020\end{array}$ & Enugu state & Not stated \\
\hline GCB & $\begin{array}{l}\text { Citrus aurantifolia leaves (15\%), mangifera } \\
\text { indica leaves }(13 \%) \text {, vernonia amygdalina } \\
\text { leaves }(12 \%) \text {, saccharum officinarum leaves } \\
(11.5 \%) \text {, allium sativum }(10.5 \%) \text {, caramel } \\
(1.5 \%) \text {, moringa oleifera }(10 \%) \text {, water (q.s). }\end{array}$ & $\begin{array}{l}\text { Aug } 2017- \\
\text { July } 2020\end{array}$ & Lagos state & NAFDAC \\
\hline GHM & $\begin{array}{l}31 \text { roots and herbs, fruits, barks (Not } \\
\text { specified). }\end{array}$ & $\begin{array}{l}\text { Jan } 2018-\text { Jan } \\
2022\end{array}$ & $\begin{array}{l}\text { Anambra } \\
\text { state }\end{array}$ & Not stated \\
\hline
\end{tabular}

Table2. Source and ingredients of powdered herbal drugs sold within Port Harcourt metropolis

\begin{tabular}{|l|l|l|l|l|}
\hline $\begin{array}{l}\text { Herbal } \\
\text { drugs code }\end{array}$ & Ingredients & $\begin{array}{l}\text { Expiration } \\
\text { timeline }\end{array}$ & $\begin{array}{l}\text { State of } \\
\text { production in } \\
\text { Nigeria and } \\
\text { environ }\end{array}$ & $\begin{array}{l}\text { Regulatory } \\
\text { Registration }\end{array}$ \\
\hline GSH & $\begin{array}{l}\text { Panax ginseng }(20 \%), \text { aloe-vera (30\%), } \\
\text { zingiber officinale }(25 \%), \text { carica papaya } 2017-\text { Jan } \\
(20 \%) .\end{array}$ & $\begin{array}{l}\text { Kumasi, } \\
\text { Ghana }\end{array}$ & Not stated \\
\hline ORG & $\begin{array}{l}\text { Carica papaya (4\%), mangifera indica } \\
(15 \%), \quad \text { Apr 2017 - } \\
\text { newbouidia leaves (22\%), }\end{array}$ & $\begin{array}{l}\text { Apr 2020 } \\
\text { state }\end{array}$ & NAFDAC \\
\hline
\end{tabular}


Composition of Potential Heavy Metal Contaminants in Selected Liquid and Powdered Herbal Medicines Commonly Sold in Port Harcourt Metropolis, Nigeria

\begin{tabular}{|c|c|c|c|c|}
\hline & $\begin{array}{l}\text { azadirachta indica }(25 \%) \text {, jasminum } \\
\text { officiorli }(7 \%) \text {, aloe barbadensis }(20 \%) \text {, } \\
\text { ginseng }(7 \%) \text {. }\end{array}$ & & & \\
\hline MHP & $\begin{array}{l}\text { Zingiber officinale }(4 \mathrm{~g}) \text {, psidium guajava } \\
(4 \mathrm{~g}) \text {, xylopia aethiopica }(2 \mathrm{~g}) \text {, cymbopogon } \\
\text { citratus }(4 \mathrm{~g}) \text {, aloe-vera }(4 \mathrm{~g}) \text {, ginseng }(2 \mathrm{~g}) \text {. }\end{array}$ & $\begin{array}{l}\text { Jun } 2017- \\
\text { May } 2020\end{array}$ & Abia state & NAFDAC \\
\hline UNP & $\begin{array}{l}\text { Aloe-vera plant, ginseng plant, moringa } \\
\text { plant. }\end{array}$ & $\begin{array}{l}\text { Jun } 2017- \\
\text { Dec } 2022\end{array}$ & Edo state & Not stated \\
\hline GWM & $\begin{array}{l}\text { Mangifera indica }(5 \mathrm{~g}) \text {, carica papaya }(3 \mathrm{~g}) \text {, } \\
\text { psidium guajoba }(6.9 \mathrm{~g}) \text {, bread fruit } \\
(11.11 \mathrm{~g}) \text {, masularia acuminate }(4.4 \mathrm{~g}) \text {, citrus } \\
\text { limon }(2.22 \mathrm{~g}) \text {, zingiber officinale }(2.22 \mathrm{~g}) \text {, } \\
\text { cymbopogon spp }(3.33 \mathrm{~g}) \text {. }\end{array}$ & $2018-2021$ & $\begin{array}{l}\text { Anambra } \\
\text { state }\end{array}$ & NAFDAC \\
\hline
\end{tabular}

\subsection{Reagents}

Several analytical grade reagents were used for sample preparation, they include: $\mathrm{HNO}_{3} 69 \%(\mathrm{v} / \mathrm{v})$ Analar (BDH, Poole, United Kingdom), HCl 37 \% (v/v) (Sigma-Aldrich, Steinheim, Germany), working standards of $\mathrm{Cd}, \mathrm{Cr}, \mathrm{Cu}$ and $\mathrm{Mn}$ were prepared by diluting concentrated stock solutions of $1,000 \mathrm{mg} / \mathrm{L}$ (AccuNoHaz, New Haven, CT, USA) to working concentrations of $0.5 \mathrm{mg} / \mathrm{L}, 1.0 \mathrm{mg} / \mathrm{L}$, $2.0 \mathrm{mg} / \mathrm{L}, 5.0 \mathrm{mg} / \mathrm{L}$ and $10.0 \mathrm{mg} / \mathrm{L}$ respectively.

\subsection{Sample Preparation}

\subsubsection{Liquid Herbal Medicines}

Nine (9) liquid herbal medicines/products were prepared for heavy metal analysis. $25 \mathrm{ml}$ of each herbal concoction in liquid dosage forms was transferred into $125 \mathrm{ml}$ glass beakers. Exactly $5 \mathrm{ml}$ of concentrated $\mathrm{HNO} 3$ was added, the mixture was heated on a hot plate with medium evaporation to about $5 \mathrm{ml}$. Conc. HNO3 acid addition continued with slow heating until the digestion was complete as depicted by a clear solution. Afterwards, beaker was left to cool before its content was being quantitatively transferred into $25 \mathrm{ml}$ volumetric flask and diluted to mark with distilled water (APHA, 1995). The diluted herbal extracts and reagent blank was aspirated into the GBC Avanta PM A6600 flame atomic absorption spectrophotometer for heavy metal analysis. The concentration units were reported as $\mathrm{mg} / \mathrm{l}$.

\subsubsection{Powdered Herbal Medicines}

Five (5) powdered herbal medicines/products were prepared for heavy metal analysis. $2.5 \mathrm{~g}$ each of the herbal concoctions in powder dosage forms were transferred into $125 \mathrm{ml}$ glass beakers. Exactly 10 $\mathrm{ml}$ of conc. HNO3 was added and mixture was pre-digested at room temperature under the fume hood (this was left overnight), the solution was then heated carefully at low heat on a hot plate until all nitrous oxide fumes had completely evolved. A $4 \mathrm{ml}$ portion of $70 \%$ perchloric acid ( $\mathrm{HClO} 4)$ before being further heated to near-dryness on the hot plate. The concentrated acid-digest was left to cool and immediately filtered into $25 \mathrm{ml}$ volumetric flask using whatman filter paper no. 42. The wall of the glass beaker was rinsed profusely and filtrate was diluted to mark with distilled water (Umar et al., 2016). Sample extracts and reagent blank was aspirated into the GBC Avanta PM A6600 Flame Atomic Absorption Spectrophotometer (FAAS) and the corresponding analyte concentrations were reported in $\mathrm{mg} / \mathrm{kg}$ units.

\subsubsection{Chemical Analysis}

The concentrations of $\mathrm{Cd}, \mathrm{Cr}, \mathrm{Cu}$, and $\mathrm{Mn}$ in the concentrated herbal extracts were determined using the flame atomic absorption spectrometer (GBC Avanta PM, A6600 model, Australia). Table 3 reflects the information on working conditions of the flame atomic absorption spectrophotometer. 
Composition of Potential Heavy Metal Contaminants in Selected Liquid and Powdered Herbal Medicines Commonly Sold in Port Harcourt Metropolis, Nigeria

Table3. Working conditions of the FAAS

\begin{tabular}{|l|l|l|l|l|l|l|l|l|l|l|}
\hline & \multicolumn{9}{|l|}{ Flame Composition } \\
\hline Metals & $\begin{array}{l}\text { Slit } \\
\text { width } \\
(\mathrm{nm})\end{array}$ & Noise & $\begin{array}{l}\text { Wave } \\
\text { length } \\
(\mathrm{nm})\end{array}$ & $\begin{array}{l}\text { Lamp } \\
\text { current } \\
(\mathrm{mA})\end{array}$ & $\begin{array}{l}\text { Calibr } \\
- \text {-ation } \\
\text { range } \\
(\mathrm{mg} / \mathrm{L} \\
)\end{array}$ & $\begin{array}{l}\text { Acetylene } \\
\text { flow rate } \\
(\mathrm{L} / \mathrm{min})\end{array}$ & $\begin{array}{l}\text { Air } \\
\text { flow } \\
\text { rate } \\
(\mathrm{L} / \mathrm{mi} \\
\mathrm{n})\end{array}$ & $\begin{array}{l}\text { Nebulizer } \\
\text { uptake } \\
\text { rate } \\
(\mathrm{ml} / \mathrm{min})\end{array}$ & $\begin{array}{l}\text { Charact- } \\
\text { eristic } \\
\text { concentr } \\
\text { ation } \\
(\mathrm{mg} / \mathrm{L})\end{array}$ & $\begin{array}{l}\text { Concentr } \\
\text {-ation of } \\
\text { Check } \\
\text { standard } \\
\text { solution } \\
(\mathrm{mg} / \mathrm{L})\end{array}$ \\
\hline $\mathrm{Cd}$ & 0.50 & 1.0 & 228.80 & 3.00 & $\begin{array}{l}0.01- \\
1.8\end{array}$ & 2.00 & 11.50 & 5.0 & 0.001 & 0.5 \\
\hline $\mathrm{Cr}$ & 0.20 & 1.0 & 357.90 & 6.00 & $\begin{array}{l}0.06- \\
15.0\end{array}$ & 2.00 & 11.50 & 5.0 & 0.006 & 1.0 \\
\hline $\mathrm{Cu}$ & 0.50 & 1.0 & 324.70 & 3.00 & $\begin{array}{l}0.02- \\
5.0\end{array}$ & 2.00 & 11.50 & 5.0 & 0.002 & 0.5 \\
\hline $\mathrm{Mn}$ & 0.20 & 1.0 & 279.50 & 5.00 & $\begin{array}{l}0.03- \\
3.6\end{array}$ & 2.00 & 11.50 & 5.0 & 0.003 & 1.0 \\
\hline
\end{tabular}

\subsubsection{Quality Assurance/Quality Control (QA/QC) Procedure}

The quality assurance and control measures employed during the analysis include the use of reagent blanks, sample triplicate run and method of spike recovery. The reagent blank (digested acid reagent only) was analyzed alongside metals of interest. Each batch of sample run ended with the aspiration of a reagent blank; this was useful for correcting spike in metal concentrations which may have been introduced from reagent impurities. The method of spike recovery was applied by introducing known concentrations of heavy metals before the process of sample digestion and analysis; this was done to determine the effectiveness of the sample preparation protocol. The percentage spike recoveries of the different metals are listed in table 4. The values obtained ranged from $91.02-102.23 \%$ which is acceptable. The relative standard deviation between analyses was $\pm 5.8 \%$. The limits of detection and quantification (LODs and LOQs respectively) were evaluated on the basis of the noise obtained for the analysis of the blank samples $(n=3)$. The LOD and LOQ were defined as the concentration of analyte that produced a signal-to-noise ratio of 3 and 10 respectively. The value of LOD and LOQ (in $\mathrm{mg} / \mathrm{kg}$ ) for each test metal is given in Table 4.

Table4. Spike recovery, limits of detection and quantification for the heavy metals

\begin{tabular}{|l|l|l|l|l|l|l|}
\hline Metals & $\begin{array}{l}\text { LOD } \\
(\mathrm{mg} / \mathrm{kg})\end{array}$ & $\begin{array}{l}\text { LOQ } \\
(\mathrm{mg} / \mathrm{kg})\end{array}$ & $\begin{array}{l}\text { Quantity of } \\
\text { standard added } \\
(\mathrm{mg} / \mathrm{kg})\end{array}$ & $\begin{array}{l}\text { Quantity } \\
\text { determined } \\
(\mathrm{mg} / \mathrm{kg})\end{array}$ & $\begin{array}{l}\text { Sample } \\
\text { concentration } \\
(\mathrm{mg} / \mathrm{kg})\end{array}$ & $\begin{array}{l}\text { Percentage } \\
\text { recovery }(\%)\end{array}$ \\
\hline $\mathrm{Cd}$ & 0.0003 & 0.001 & 0.50 & 0.78 & 0.35 & 91.02 \\
\hline $\mathrm{Cr}$ & 0.002 & 0.01 & 1.00 & 1.15 & 0.21 & 94.78 \\
\hline $\mathrm{Cu}$ & 0.001 & 0.004 & 0.50 & 0.83 & 0.40 & 91.57 \\
\hline $\mathrm{Mn}$ & 0.001 & 0.004 & 1.00 & 2.24 & 1.19 & 102.23 \\
\hline
\end{tabular}

$\%$ recovery $=\underline{\text { amount of pure product recovered }(\mathrm{g})} \times 100$

amount of crude material used $(g)$

\subsection{Statistical Analysis}

Descriptive statistics was carried out using statistical package for Social Science. Data was expressed as mean \pm standard deviation. The range (minimum and maximum) of the values obtained for each herbal drug brand was also presented. One way analysis of variance was carried out and WallerDuncan statistics was used to compare the mean values of each test parameter under investigation in the liquid herbal products.

Table5. Levels of heavy metals in liquid herbal medicines sold in Port Harcourt metropolis

\begin{tabular}{|l|l|l|l|l|}
\hline Sample Identity & $\mathrm{Cr}(\mathrm{mg} / \mathrm{l})$ & $\mathrm{Cu}(\mathrm{mg} / \mathrm{l})$ & $\mathrm{Cd}(\mathrm{mg} / \mathrm{l})$ & $\mathrm{Mn}(\mathrm{mg} / \mathrm{l})$ \\
\hline YCB & $<0.001 \pm 0.000$ & $0.447 \pm 0.025 \mathrm{e}$ & $<0.001 \pm 0.000$ & $0.041 \pm 0.001 \mathrm{a}$ \\
\hline UAM & $<0.001 \pm 0.000$ & $0.064 \pm 0.001 \mathrm{bc}$ & $<0.001 \pm 0.000$ & $0.645 \pm 0.042 \mathrm{~g}$ \\
\hline RHB & $<0.001 \pm 0.000$ & $0.085 \pm 0.001 \mathrm{c}$ & $<0.001 \pm 0.000$ & $0.613 \pm 0.010 \mathrm{f}$ \\
\hline GHM & $<0.001 \pm 0.000$ & $0.081 \pm 0.001 \mathrm{c}$ & $<0.001 \pm 0.000$ & $0.362 \pm 0.011 \mathrm{~d}$ \\
\hline SHM & $<0.001 \pm 0.000$ & $0.046 \pm 0.002 \mathrm{~b}$ & $<0.001 \pm 0.000$ & $0.982 \pm 0.010 \mathrm{~h}$ \\
\hline
\end{tabular}


Composition of Potential Heavy Metal Contaminants in Selected Liquid and Powdered Herbal Medicines Commonly Sold in Port Harcourt Metropolis, Nigeria

\begin{tabular}{|l|l|l|l|l|}
\hline UNC & $<0.001 \pm 0.000$ & $2.541 \pm 0.039 \mathrm{f}$ & $<0.001 \pm 0.000$ & $0.654 \pm 0.003 \mathrm{~g}$ \\
\hline GCH & $<0.001 \pm 0.000$ & $<0.001 \pm 0.000 \mathrm{a}$ & $<0.001 \pm 0.000$ & $0.461 \pm 0.001 \mathrm{e}$ \\
\hline EFM & $<0.001 \pm 0.000$ & $0.145 \pm 0.001 \mathrm{~d}$ & $<0.001 \pm 0.000$ & $0.206 \pm 0.003 \mathrm{~b}$ \\
\hline GCB & $<0.001 \pm 0.000$ & $<0.001 \pm 0.000 \mathrm{a}$ & $<0.001 \pm 0.000$ & $0.271 \pm 0.002 \mathrm{c}$ \\
\hline
\end{tabular}

Data is expressed as mean \pm standard deviation; Different letters along the column indicate significant variations $(\mathrm{P}<0.05)$ according to Waller Duncan statistics.

Table 5 represents the level of selected heavy metals in liquid herbal solutions sold within Port Harcourt metropolis, Nigeria. Chromium and cadmium were not detected in any of the liquid herbal medicines. The concentration of copper was not detected in two (2) of the nine (9) finished herbal products. UNC $(2.541 \pm 0.039 \mathrm{mg} / \mathrm{l})$ and $\mathrm{GCH} / \mathrm{GCB}(<0.001 \pm 0.000 \mathrm{mg} / \mathrm{l})$ were the highest and lowest concentrations of copper respectively, while SHM $(0.982 \pm 0.010 \mathrm{mg} / \mathrm{l})$ and YCB $(0.041 \pm$ $0.001 \mathrm{mg} / \mathrm{l})$ were the highest and lowest concentrations of manganese in the finished liquid herbs. The mean concentration of copper in RHB and GHM was $0.085 \pm 0.001 \mathrm{mg} / \mathrm{l}$ and $0.081 \pm 0.001 \mathrm{mg} / \mathrm{l}$ respectively. Statistically, there was no significant difference $(\mathrm{P}>0.05)$ between the two herbal products. Similarly, GCH and GCB were both observed below detection limit. Consequently, they showed no significant variation $(\mathrm{P}>0.05)$. All other samples depicted significant variation $(\mathrm{P}<0.05)$. Also, manganese depicted significant variation $(\mathrm{P}<0.05)$ for all liquid herbal products except for $\operatorname{UAM}(0.645 \pm 0.042 \mathrm{mg} / \mathrm{l})$ and $\mathrm{UNC}(0.654 \pm 0.003 \mathrm{mg} / \mathrm{l})$.

Table6. Levels of heavy metals in powdered herbal drugs sold in Port Harcourt metropolis

\begin{tabular}{|l|l|l|l|l|}
\hline Sample Identity & $\mathrm{Cr}(\mathrm{mg} / \mathrm{kg})$ & $\mathrm{Cu}(\mathrm{mg} / \mathrm{kg})$ & $\mathrm{Cd}(\mathrm{mg} / \mathrm{kg})$ & $\mathrm{Mn}(\mathrm{mg} / \mathrm{kg})$ \\
\hline MHP & $0.134 \pm 0.004 \mathrm{c}$ & $<0.001 \pm 0.000$ & $1.316 \pm 0.016 \mathrm{c}$ & $<0.001 \pm 0.000$ \\
\hline GWM & $0.049 \pm 0.001 \mathrm{a}$ & $<0.001 \pm 0.000$ & $0.864 \pm 0.005 \mathrm{~b}$ & $<0.001 \pm 0.000$ \\
\hline UNP & $0.143 \pm 0.001 \mathrm{~d}$ & $<0.001 \pm 0.000$ & $1.019 \pm 0.011 \mathrm{~b}$ & $<0.001 \pm 0.000$ \\
\hline ORG & $0.143 \pm 0.001 \mathrm{~b}$ & $<0.001 \pm 0.000$ & $2.587 \pm 0.314 \mathrm{~d}$ & $<0.001 \pm 0.000$ \\
\hline GS & $0.069 \pm 0.001 \mathrm{~b}$ & $<0.001 \pm 0.000$ & $0.437 \pm 0.032 \mathrm{a}$ & $<0.001 \pm 0.000$ \\
\hline
\end{tabular}

Data is expressed as mean \pm standard deviation; Different letters along the column indicate significant variations $(\mathrm{P}<0.05)$ according to Waller Duncan statistics.

The concentration of copper and manganese in powdered herbal products were reportedly below detection limit of the instrument. The mean concentration of chromium in ORG and GS was $0.143 \pm$ $0.001 \mathrm{mg} / \mathrm{kg}$ and $0.069 \pm 0.001 \mathrm{mg} / \mathrm{kg}$ respectively. UNP $(0.143 \pm 0.001 \mathrm{mg} / \mathrm{kg})$ and ORG $(0.143 \pm$ $0.001 \mathrm{mg} / \mathrm{kg}$ ) showed the highest chromium concentrations while the lowest chromium concentration was observed for GWM $(0.049 \pm 0.001 \mathrm{mg} / \mathrm{kg})$. Statistically, there was no significant difference $(\mathrm{P}>0.05)$ between the two herbal products. Apart from ORG and GS, all other powdered herbal products were significantly different $(\mathrm{P}<0.05)$ for chromium. On the other hand, the highest and lowest concentrations of cadmium were ORG $(2.587 \pm 0.314 \mathrm{mg} / \mathrm{kg})$ and GS $(0.437 \pm 0.032 \mathrm{mg} / \mathrm{kg})$ respectively. In addition, cadmium depicted significant variation $(\mathrm{P}<0.05)$ for all powdered herbal products except for GWM $(0.864 \pm 0.005 \mathrm{mg} / \mathrm{kg})$ and UNP $(1.019 \pm 0.011 \mathrm{mg} / \mathrm{kg})($ table 6$)$.

\section{RESULTS AND DISCUSSION}

The level of the heavy metals in different brands of liquid and powdered herbal dose is presented in tables 5 and 6 . The heavy metal content reflected a wide range of variation according to the different brands. The variation that exists among the brands could be due to difference in source of plant materials used, herbal preparation methods (drying, grinding and extraction), packaging processes and possible contamination from poor manufacturing practices and exogenous sources. Plants are major ingredients of the herbal concoctions. Hence, the likelihood of heavy metal uptake during plant cultivation is possible.

\subsection{Cadmium}

The content of $\mathrm{Cd}$ in herbal medicines ranged from $0.437-2.587 \mathrm{mg} / \mathrm{kg}$ for powdered herbal drugs while $\mathrm{Cd}$ was reportedly below measurable detection limit in liquid herbal preparations. Cd is not required by biological diversity as such its permissible limit has been stipulated as $0.3 \mathrm{ppm}$, recommended by world health organization (WHO) as indication of toxicity (WHO, 2007). Even though $\mathrm{Cd}$ was not found in liquid herbal preparations, they exceeded regulatory limits for all 
powdered herbs; this indicates a cause for concern. The Cd values in this study had similarities with previous works that reported concentration in the range of $1.53-3.23 \mu \mathrm{g} / \mathrm{g}$ in Kano herbal preparations for major disease conditions (Samali et al., 2017), selected herbal medicines sold in Lagos state, Nigeria reported Cd values ranging from $0.48-3.08 \mu \mathrm{g} / \mathrm{g}$ (Onwordi et al., 2015), but lower $\mathrm{Cd}$ concentrations ranging from $<0.001-0.08 \mathrm{mg} / \mathrm{kg}$ were reported for some Indian medicinal plants (Singh et al., 2014), $0.0045-0.1601$ ppm in herbal medicine/preparations sold in Kano state, Nigeria (Umar et al., 2016). Mean level of Cd $(0.053 \mu \mathrm{g} / \mathrm{g})$ was also reported for traditionally used herb ceropegia juncea (Roxb.) (Karayil et al., 2014). Consuming lower levels of cadmium over a long period of time can lead to build up of cadmium in the kidneys, with significant levels leading to kidney damage. Anemia, liver disease, nerve or brain damage, as well as lung cancer have been observed in exposed persons (ATSDR, 2012). Cd is highly toxic and could result in the death of cells and or increase its multiplication (Iwegbue et al., 2015). Consequently, the levels of Cd obtained in this study indicate potential toxicity and immediate public health concern.

\subsection{Chromium}

The level of $\mathrm{Cr}$ in the herbal products under study varied from $0.049-0.143 \mathrm{mg} / \mathrm{kg}$ for powdered forms while the liquid extracts were reportedly below measurable detection limit of the instrument. The values obtained in this study were lower than the permissible limit of $2 \mathrm{ppm}$ set by Canada for raw herbal materials (WHO, 2007). The values reported in this study were close to the range reported in other herbal products. Some of the previous values ranged from $0.0418-0.2092 \mathrm{mg} / \mathrm{kg}$ in herbal medicine/preparations sold in Kano state, Nigeria (Umar et al., 2016), $0.036 \mathrm{mg} / \mathrm{kg}$ in traditionally used herb ceropegia juncea (Roxb.) (Karayil et al., 2014). On the other hand, assessment of some indian medicinal plants revealed higher concentrations of $0.79-1.88 \mathrm{mg} / \mathrm{kg}$ (Singh et al., 2014). Generally, $\mathrm{Cr}$ is an important mineral required for the biosynthesis of glucose tolerance factor (Prashanth et al., 2015). Long term exposure to higher concentrations of $\mathrm{Cr}$ could result in skin cancer and dermatitis, kidney, stomach and respiratory tract defects (Prashanth et al., 2015; Iwegbue et al., 2015). They can also cause sperm damage, especially in male reproductive systems (ATSDR, 2012). However, the levels obtained in this study pose no toxicity risk due to chromium.

\subsection{Copper}

$\mathrm{Cu}$ was observed in the range of $<0.001-2.541 \mathrm{mg} / \mathrm{l}$ for liquid herbs while the powdered herbs were reportedly below measurable detection limit of the instrument. The values were lower than the permissible limit of $150 \mathrm{ppm}$ stipulated by Singapore for raw herbal materials (WHO, 2007). Highest concentration of $\mathrm{Cu}$ was recorded in UNC (2.541 ppm). Higher concentrations have been reported in some herbal products in Nigeria. Copper was detected in the range of $4.94-10.03 \mathrm{mg} / \mathrm{kg}$ in Kano herbal preparations for major disease conditions (Samali et al., 2017), a mean value of $4.14 \pm 0.02$ $\mathrm{mg} / \mathrm{kg}$ in selected herbal medicines sold in Lagos (Onwordi et al., 2015). But the findings were in consonance with the range of $0.0418-0.2092 \mathrm{mg} / \mathrm{kg}$ in herbal medicine/preparations sold in Kano state, Nigeria. $\mathrm{Cu}$ is essential for good health and necessary for several metabolic and biochemical activities coupled with bone development, haemoglobin synthesis and connective tissue metabolism (ATSDR, 2004; Palacios, 2006; Prashanth et al., 2015). Exposure to high doses can cause headache, dizziness, nausea, and diarrhea. Also, nausea, vomiting, stomach cramps, or diarrhea are commonplace, while excessive intake can result in liver and kidney damage and even death (ATSDR, 2004). The levels of $\mathrm{Cu}$ in this study pose no public health concern.

\subsection{Manganese}

The concentration of $\mathrm{Mn}$ in the herbal products ranged from $0.041-0.902 \mathrm{mg} / \mathrm{l}$ for herbs in liquid dosages while herbs in powdered dosages were reportedly observed below measurable detection limit. There was no basis for comparing the values reported in this study, this is because permissible limits are yet to be specified for $\mathrm{Mn}$ in herbal products. The values reported in other herbal concoctions were within the range reported in this study. Some of the results of previous works ranged from $0.0123-$ $1.4462 \mathrm{mg} / \mathrm{kg}$ in herbal medicine/preparations sold in Kano state, Nigeria (Umar et al., 2016), 0.017 $\mu \mathrm{g} / \mathrm{g}$ in traditionally used herb ceropegia juncea (Roxb.) (Karayil et al., 2014). Higher concentration ranging from $57.57-65.05 \mathrm{mg} / \mathrm{kg}$ was reported for Kano herbal preparations for major disease conditions. $\mathrm{Mn}$ is an essential nutrient required daily in small quantities to stay healthy (ATSDR, 
2012). It is a cofactor for several enzymes and it is needed for biosysnthesis of mucopolysaccharides in bone development (Palacios, 2006), fatty acids and cholesterol metabolisms, and oxidative phosphorylation (Prashanth et al., 2015). Deficiency of Mn can lead to bleeding disorder (Prashanth et al., 2015). Excessive Mn intake can lead to the irritation of lungs and consequently result in pneumonia. Loss of sex drive and sperm damage has also been observed in men, while respiratory effects and nervous system disturbances are common adverse implications of high doses (ATSDR, 2012).

\section{CONCLUSION}

The levels of most heavy metals were in compliance with permissible limits recommended by WHO for raw herbal materials. However, the significant concentration of cadmium in all the powdered herbs may portend serious health concern for members of the public that consume these products. Even though all the tested herbal products were branded not all were registered with NAFDAC. Therefore, it is imperative that NAFDAC establish a more stringent level of regulation and control of herbal products sold in Nigeria. All stakeholders should be implored to collaborate with the local regulatory authority to purge the country of fake and unhealthy drugs which can only be possible when these products are subjected to scientific verification. The circumvention of NAFDAC certification processes by herbal medicine dealers should be nipped in the bud by providing adequate access to information on product registration across all states in Nigeria, clarifying laws and regulations to the regulated industry, and continued insistence on clean and hygienic production conditions as prerequisite for product registration. Overall, herbs in liquid dosage forms appear to be healthier alternatives when compared to those of powdery appearance. Residents of Port Harcourt metropolis who consume herbal products in powdered dosages are more susceptible to kidney and liver damage resulting from excessive consumption of $\mathrm{Cd}$, this health condition ultimately results in death when not properly managed.

\section{ACKNOWLEDGEMENT}

The author is indebted to Anal Concept Limited Port Harcourt, Nigeria for providing the laboratory facilities and technical support to carry out this research.

\section{REFERENCES}

[1] Adepoju-Bello, A. A., Issa, O. A., Oguntibeju, O. O., Ayoola, G. A., Adejumo, O. O. (2012). Analysis of some selected toxic metals in registered herbal products manufactured in Nigeria. African Journal of Biotechnology, 11(26): 6918-6922.

[2] Agency for Toxic Substances and Disease Registry (ATSDR) (2004). Toxicological Profile for Copper. U.S. Department of Health and Human Services, Atlanta, GA.

[3] Agency for Toxic Substances and Disease Registry (ATSDR) (2012). Toxicological Profile for Cadmium. U.S. Department of Health and Human Services, Atlanta, GA.

[4] Agency for Toxic Substances and Disease Registry (ATSDR) (2012). Toxicological Profile for Chromium. U.S. Department of Health and Human Services, Atlanta, GA.

[5] Agency for Toxic Substances and Disease Registry (ATSDR) (2012). Toxicological Profile for Manganese. U.S. Department of Health and Human Services, Atlanta, GA.

[6] Aigberua, A. O., Ekubo, A. T., Inengite, A. K., Izah, S. C. (2016). Evaluation of Total Hydrocarbon Content and Polycyclic Aromatic Hydrocarbon in an Oil Spill Contaminated Soil in Rumuolukwu Community in Niger Delta. J. Environ. Treat. Tech., 4(4): 130-142.

[7] Ambe, B. A., Eja, I. E., Agbor, C. E. (2015). Assessment of the impacts and people's perception of bush burning on the grasslands and montane ecosystems of the Obanliku Hills/Plateau, Cross River State, Nigeria. Journal of Natural Sciences Research, 5(6): 12-20.

[8] American Public Health Association (APHA) (1992). Standard Methods for the Examination of Water and Wastewater. $18^{\text {th }}$ ed. Washington D.C, USA.

[9] American Public Health Association (APHA) (1995). Standard Methods for the Examination of Water and Wastewater. $19^{\text {th }}$ ed. Washington D.C, USA.

[10] Bushra, H., Ghazala, H. R., Shahid, N. (2011). Determination of toxic metals in some herbal drugs through Atomic Absorption Spectroscopy. Pakistan Journal of Pharmaceutical Science, 24(3): 352-358.

[11] Carter, I. (2001). Footsteps: A quarterly newsletter linking development workers around the world. In, (Tearfund, England). 
[12] Chan, K. (2003). Some aspects of toxic contaminants in herbal medicines. Chemosphere, 52: 1361-1371.

[13] Cooper, K., Noller, B., Connell, D., Yu, J., Sadler, R., Olszowy, H., Golding, G., Tinggi, U., Moore, M. R., Myers, S. (2007). Public Health risks from heavy metals and metalloids present in traditional Chinese medicines. J. Toxicol. Environ. Health, Part A Curr. Iss. 70: 1694-1699.

[14] Ekeanyanwu, R. C., Njoku, J. O., Nwodu, P. O., Njokuobi, A. E. (2013). Analysis of Some Selected Toxic Heavy Metals in Some Selected Toxic Heavy Metals in Some Branded Nigerian Herbal Products. Journal of Applied Pharmaceutical Science, 3(4): 088-091.

[15] Esimone, C. O., Chah, K. F., Ikejide, S. C. (2002). Microbiological quality of herbal preparations marketed in Southeast Nigeria. J. Nat Remedies, 2:42-48.

[16] Gasser, U., Klier, B., Kuhn, A. V., Steinhoff, B. (2009). Current Findings on the Heavy Metal Content in Herbal Drugs. Pharmeuropa Scientific Notes 2009-1, Germany.

[17] Idris, M. A., Kolo, B. G., Garba, S. T., Waziri, I. (2013). Pharmaceutical industrial effluent: heavy metal contamination of surface water in Minna, Niger State, Nigeria. Bull. Environ Pharm Life Sci, 2(3): 40-44.

[18] Izah, S. C., Chakrabarty, N., Srivastav, A. L. (2016). A Review on Heavy Metal Concentration in Potable Water Sources in Nigeria: Health Effects and Mitigating Measures. Exposure and Health, 8: 285-304.

[19] Izah, S. C., Aigberua, A. O. (2017). Comparative Assessment of Selected Heavy Metals in Some Common Edible Vegetables Sold in Yenagoa Metropolis, Nigeria. Journal of Biotechnology Research, 3(8): 66-71.

[20] Izah, S. C., Inyang, I. R., Angaye, T. C. N., Okowa, I. P. (2017a). A review of heavy metal concentration and potential health implications in beverages consumed in Nigeria. Toxics, 5(1): 1-5.

[21] Izah, S. C., Bassey, S. E., Ohimain, E. I. (2017b). Removal of Heavy Metals in Cassava Mill Effluents with Saccharomyces Cerevisiae isolated from Palm Wine. MOJ Toxicology, 3(4): 00057.

[22] Izah, S. C., Angaye, T. C. N., Aigberua, A. O., Nduka, J. O. (2017c). Uncontrolled Bush Burning in the Niger Delta Region of Nigeria: Potential Causes and Impacts on Biodiversity. International Journal of Molecular Ecology and Conservation, 7(1): 1-16.

[23] Izah, S. C., Uhunmwangho, E. J., Eledo, B. O. (2018a). Medicinal potentials of Buchholzia Coriacea (Wonderful Kola). Medicinal Plant Research, 8(5): 27-43.

[24] Izah, S. C., Zige, D. V., Alagoa, K. J., Uhunmwangho, E. J., Iyamu, A. O. (2018b). Antibacterial Efficacy of Aqueous Extract of Myristica fragrans (Common Nutmeg). EC Pharmacology and Toxicology, 6(4): 291-295.

[25] Jaishankar, M., Tseten, T., Anbalagan, N., Matthew, B. B., Beeregowda, K. N. (2014). Toxicity, mechanism and health effects of some heavy metals. Interdiscip Toxicol, 7(2): 60-72.

[26] Jarup, L. (2003). Hazards of heavy metal contamination. Br Med Bull, 68(1): 167-182.

[27] Kabata-Pendias, A., Pendias, H. (2001). Trace Elements in Soils and Plants. $3^{\text {rd }}$ ed. CRC Press LLC, New York, Washington D.C.

[28] Karayil, S., Bhavani., Vivek. Ch. (2014). Heavy Metal Analysis from Traditionally used Herb Ceropegia juncea (Roxb.).

[29] Nduka, J. O., Aigberua, A. O. (2018). Heavy Metals and Physicochemical Characteristics of Soils from the Banks of Effluent Wastewater Retention Pits in the Niger Delta. Biotechnol Res, 4(1): 48-53.

[30] Odukoya, A. M., Abimbola, A. F. (2010). Contamination assessment of surface and ground water within and around two dumpsites. Int. J. Environ. Sci. Tech., 7(2): 367-376.

[31] Ogbeibu, A. E., Iyobosa, S. E. (2013). Illegal crude oil bunker in Nigeria. Proximate and ultimate factors. Journal of Nigeria Environmental Society, 7(4): 1-18.

[32] Ohimain, E. I. (2013). A review of the Nigeria biofuel policy and incentives. Renewable and Sustainable Energy Reviews, 22: 246-256.

[33] Onimisi, B. H., Kasim, L. S., Bamigboye, C. Y., Adeoti, O. A. (2016). The Health Benefits of Heavy Metals in Herbal Drinks, Nigeria. Journal of Pharmaceutical Research, 1:1-5.

[34] Onwordi, C. T., Agbo, N., Ogunwande, I. A. (2015). Levels of Potentially Toxic Metals in Selected Herbal Medicines In Lagos, Nigeria. Journal of Natural Sciences Research, 5(2): 148-156.

[35] Palacios, C. (2006). The Role of Nutrients in Bone Health, from A to Z. Critical Reviews in Food Science and Nutrition, 46: 621-628.

[36] Pirzada, H., Ahmad,S. S., Rashid, A., Shah, T. (2009). Multivariate analysis of selected roadside plants (Dalbergia sissoo and cannabis sativa) for lead pollution monitoring. Pakistan Journal Bot, 41: 1729-1736. Robin, D. G., \& James, C. R. S. (2003). Trace element uptake and distribution in Plant Science, University of Adelaide Waitecompus, South Australia. 
Composition of Potential Heavy Metal Contaminants in Selected Liquid and Powdered Herbal Medicines Commonly Sold in Port Harcourt Metropolis, Nigeria

[37] Prashanth, L., Kattapagari, K. K., Chitturi, R. T., Baddam, V. R. R., Prasad, L. K. (2015). A review on role of essential trace elements in health and disease. Journal of Dr. NTR University of Health Sciences, 4(2): 75-78.

[38] Singh, K. P., Bhattacharya, S., Sharma, P. (2014). Assessment of Heavy Metal Contents of Some Indian Medicinal Plants. American-Eurasian J. Agric. \& Environ. Sci., 14(10): 1125-1129.

[39] Umar, A., Mohammed, Y., Garba, S., Faruruwa, M. D. (2016). Quantitative Determination of Heavy Metals in Some Commonly Consumed Herbal Medicines in Kano State, Nigeria. Journal of Scientific and Engineering Research, 3(2): 1-8.

[40] World Health Organization (WHO) (2007). WHO guidelines for assessing quality of herbal medicines with reference to contaminants and residues. Geneva, Switzerland.

Citation: Ayobami Omozemoje Aigberua (2019). Composition of Potential Heavy Metal Contaminants in Selected Liquid and Powdered Herbal Medicines Commonly Sold in Port Harcourt Metropolis, Nigeria. International Journal of Medicinal Plants and Natural Products (IJMPNP), 5(1), pp.30-39. http://dx.doi.org/10.20431/2454-7999.0501005

Copyright: () 2019 Authors, This is an open-access article distributed under the terms of the Creative Commons Attribution License, which permits unrestricted use, distribution, and reproduction in any medium, provided the original author and source are credited. 